\title{
UNDERSTANDING SOCIAL AND ENVIRONMENTAL ACCOUNTING
}

\author{
Norhayah Zulkifli
}

\begin{abstract}
Literature on social and environmental aspects of accounting can be found since the early 1970s and the increase in the amount of research and interest is paramount. Consequently and at the same time the idea of accounting as a transcend element portrayed by social and environmental accounting (SEA) is being adopted by many quarters in companies' accounting and reporting practices as well as management practices. Despite the substantial increase in SEA and reporting as well as management practices in many parts of the world, news on business' implications with social and environmental problems tend to persist. The effectiveness of such practices could be due to adopting SEA and reporting without proper understanding of the whole concepts underlying the discipline. In this regard, a solid understanding of SEA as a new form of accounting is crucial so that those who practice actually embrace the concepts of SEA. This article reviews and analyses the different concepts of SEA with the intention to clarify the various and sometimes vague definitions of SEA.
\end{abstract}

Keywords: Social and environmental accounting, environmental accounting, sustainability, nonconventional accounting, corporate social responsibility.

\section{Introduction}

SEA is a relatively new form of accounting (Bebbington, 1995), thus it is pertinent here to examine its concepts. To accomplish this, it is necessary to explore four discussion areas: the background of social and environmental responsibility in accounting; a discussion on conventional and non-conventional accounting; definitions of the new forms of accounting; and lastly, the concepts and theories underlying SEA.

\section{Social and Environmental Responsibility in Accounting}

The notion of social accountability was ingrained in the writings of the progressive reformers and social accountants of the early 1900s (Bloom and Heymann, 1986). In the late 1960's, such a notion found expression on American soil in the form of concern on the performance of social and economic institutions, the efficiency of the government, and the quality of life in general (Seidler, 1975). A corollary outcome of this heightened awareness of social accountability was the question of how traditional accounting could rise to the challenge posed by this evolutionary change in societal need. It was not difficult to surmise that accounting for social and environmental responsibility would entail a departure from the conventional business transaction-oriented focus, to one bordering on a measurement of social welfare. Already the early reformers were calling for greater corporate and public accountability as well as emphasising the role of accounting in monitoring abuses of

Corresponding author: Dr Norhayah Zulkifli, Senior Lecturer, Faculty of Business and Accountancy, University of Malaya (norhayah@um.edu.my). 
stewardship. In tandem with this, there was also a growing concern on the deterioration of the environment and a tendency to question the established order of society. It was under such circumstances that SEA and audit were propelled "to real prominence in the early 1970s, as a natural consequence of the debate then raging concerning the role of the corporation in society at a time of rising societal expectations and emerging environmental awareness" (Owen, 2004, p. 24).

This anxiety, to some extent, produced a surge of interest among economists, system analysts, activist lawyers and ecologists in matters pertaining to the efficient allocation of government expenditure. They were also of the view that greater responsibility should be borne by the free economy enterprise for the indirect consequences of their activities. Ways to control pollution at reasonable costs should be found. Consequently, the idea of identifying explicitly social costs and social benefits in the decision-making processes was recognised. In this regard, rather than measuring only an individual firm's contribution to shareholders' wealth, emphasis was also to be given to the measurement of an individual firm's contribution to society and the quality of life. Although accountants were in general not inclined to be directly involved in the measurement of impacts to the society and the environment, the push for "social accounting" and "social accountability" nevertheless persisted. Spurred by the ideas of Beams and Fertig (1971), Churchman (1971), Linowes (1972), and Mobley (1970) of the early 70's, other studies soon emerged to stress the importance of accounting to assume greater responsibility to the society and the environment (see Dey, 2007; Adams and Gonzalez, 2007).

\section{Conventional Accounting and SEA}

The conventional accounting system and policies are based on the paradigms implied by the classical economic theory of free markets, with the avowed emphasis on the role of private property and the use of the market mechanism to assign individual values (Bloom and Heymann, 1986; Gray et al., 1996). Accounting is thus subservient primarily to the interests of the financiers of a business enterprise. It provides business information that will help decisions to maximise profits of the financiers. It also checks on the stewardship of individuals entrusted by the financiers with the day to day running of the enterprise. In short, the main objective of the conventional model is maximisation of the financiers' wealth in the secondary belief that society at-large too will benefit. Short term gains for the financiers are allocated well in advance of impacts on individuals, communities and the environment. Cooper and Sherer (1984) assert that conventional accounting stands as a political and social process that creates its own social reality - a reality that limits all possible interactions between the 'world' and the organisation that it helped shape. While it is true that the decision usefulness and accountability theories do acknowledge the role of financial reporting as a decision making tool of various parties (AAA, 1977) as well as a monitoring mechanism of the social performance of corporations (Henderson and Peirson, 1988), by and large, the literature on decision usefulness relates only to the needs of shareholders and creditors (Mathews and Perera, 1996).

\section{Externalities and Its Implications on SEA}

As an important aspect of the free market system, corporate activities include the use of available "free goods', such as air and water, where the pollution effects are externalities rather than the internal costs of the enterprise (Gray et al., 1996). By "externalities," the economists refer to those consequences of an economic activity which are not reflected in the costs borne by the individual or organisation benefiting from the said activity (Crowther, 2000). Accounting makes possible the functions of measuring and rectifying, among others, 
activities that seek profits, economic gains and the maximisation of cash flow. By not taking into consideration, for instance, air and water pollution, which can be a consequence of some economic activities, accounting is guilty of not disseminating the full real account of the circumstances.

Since accounting is rooted in classical liberalism philosophy, it is inevitable that the discipline is only concerned with the measurement and reporting of activities that have a bearing on the individual firm. Any actions of the firm which have consequences beyond its confines are held not to be of its concern. Moreover, the free market mechanism operates by mediating between freely acting individuals to affect a kind of equilibrium that renders any fear by a particular firm of its actions upon externalities as irrelevant. As a consequence, such actions are deemed not a concern to be accounted for (Crowther, 2000). The cumulative effect of these basic values, definitions and principles, and the technical nature of accounting mean that the effects of business decisions on individuals and communities cannot be recognised and environmental impact through externalities are defined out of existence (Mathews, 1993).

SEA is an attempt to fill the gap left open by conventional accounting. It deals with these 'externalities.' However, the actual measurement of external costs and benefits is extremely difficult and fraught with problems. This is one of the main obstacles to any form of SEA (Crowther, 2000). The evaluation of the performance of an organisation is partly concerned with the measurement of performance and partly with the reporting of that performance. Accordingly, as mentioned by Crowther, there should be a corresponding recognition of the need to change the measurement and reporting of a firm when a paradigm shift happens in favour of social accountability. Crowther contends further that power is the generally recognised essential component of accountability. Greater accountability is therefore accorded to those stakeholders who have more power. One of the problems with this is that the society at large and the environment in particular, do not constitute powerful stakeholders. It is perhaps for this reason that social accountability does not feature predominantly in organisations.

SEA transcends the traditional boundaries of accounting (see Gambling, 1974; Estes, 1976, Gambling, 1978; Perks, 1993; Mathews, 1993, 1995; Gray et al., 1996; Gray and Bebbington, 2001). A considerable body of literature now exists which relates accounting to questions of economic growth and its links to social justice and development. In general, one can safely conclude that accounting plays a crucial supporting role in the construction and upholding of an economic order (Hines, 1988; Hopwood and Miller, 1994) and that SEA can lead to a new world where profits are not the sole focus of life (Lehman, 2001).

Figure 1 presents the elements that make up the conventional accounting in juxtaposition to those of SEA. It illustrates the inclusion of externalities and the perceived need to report other than economic events to groups additional to those addressed at present. It also epitomises the current failure of financial accounting and reporting in recognising its extensive social, economic, political and environmental connotations. By failing to include SEA, the implied values of conventional accounting can be questioned. Rather than accountability in the broader sense, conventional accounting is restricted to decisionusefulness and for a constrained scope of users. 


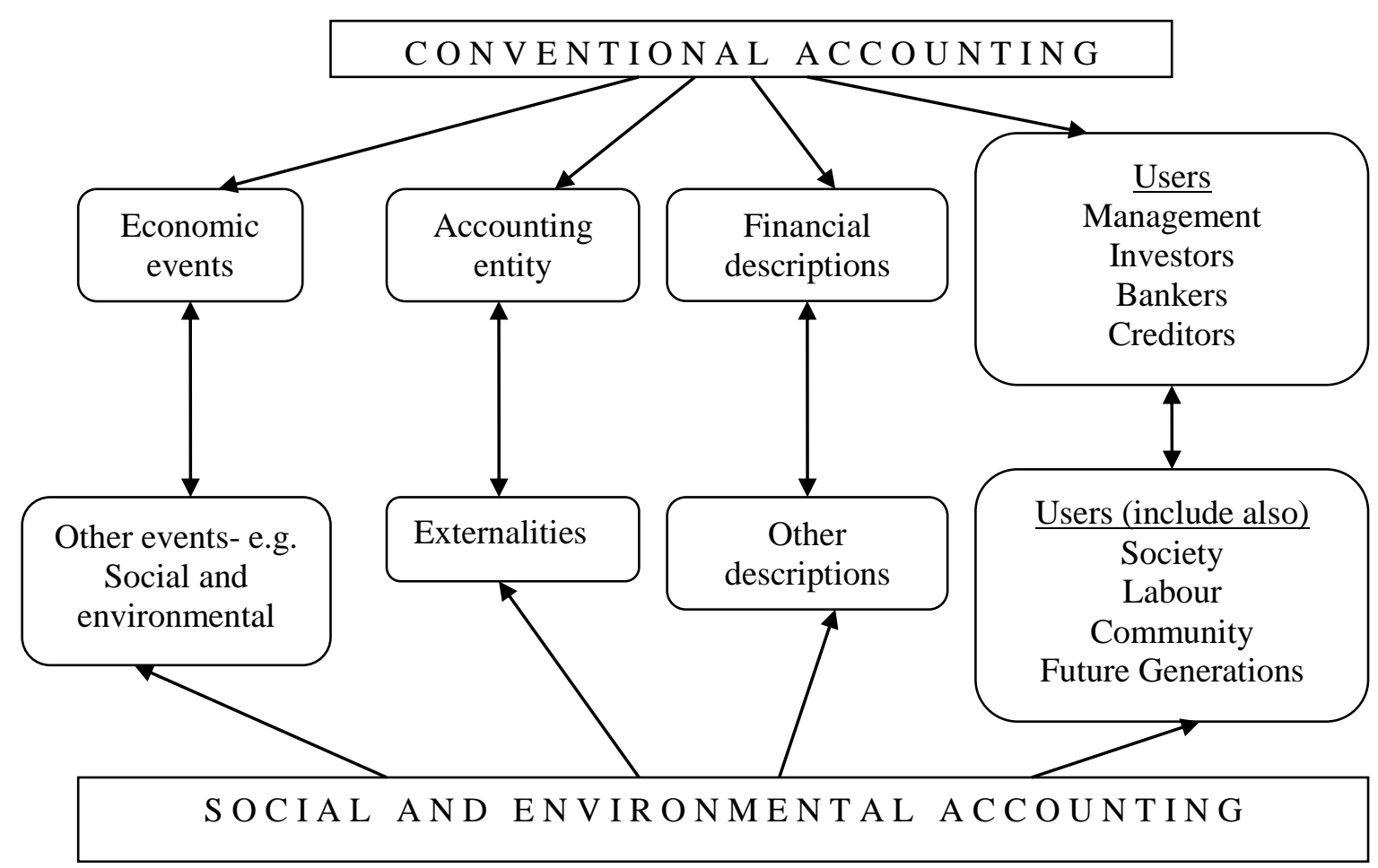

Figure 1 - Elements in conventional accounting and SEA Adapted from Gray (1991, p.5)

\section{New Forms of Accounting}

There are various terms (e.g. social accounting, corporate social reporting, environmental accounting, socially responsible accounting, corporate social responsibility) accorded to SEA and in some literature they are treated as synonymous (Stevenson, 2002). For the purpose of establishing a foundation for the understanding of SEA, this study considers it pertinent that due deliberations be given to the clarification of the strands of definitions and terminologies on the subject. Humphrey, Lewis and Owen (1996, p. 81) mention that, "choosing to study the coverage being given to SEA issues... was not without its problems, especially regarding definitional issues". Owen et al. (1994, p.15) state that, "the boundaries of the subject area are open to interpretation". For this reason, the terms associated with SEA that explain and illustrate this new body of knowledge are gathered and discussed. Although the concepts behind the various terms are mostly interrelated, efforts are made to disentangle their meanings and position the various forms of SEA.

\subsection{Social and Environmental Accounting}

SEA generally covers the issues of social accounting, responsibility and environmental matters. Its focus is on how corporate activities affect employees, the local community, the consumer and the natural environment (Owen et al., 1994). Mathews (1993, p. 64) defines these non-traditional accounting disclosures as follows:

"Voluntary disclosures of information, both qualitative and quantitative made by organisations to inform or influence a range of audiences. The quantitative disclosures may be in financial or non-financial terms." 
Gray, Owen and Maunders (1987, p. ix) also define SEA as:

"...the process of communicating the social and environmental effects of economic actions to particular interest groups within society and to society at large. As such, it involves extending the accountability of organisations (particularly companies), beyond the traditional role of providing a financial account to the owners of capital, in particular, shareholders. Such an extension is predicated upon the assumption that companies do have wider responsibilities than simply to make money for their shareholders."

These definitions imply that accounting, especially financial accounting, is by nature restricted since it confines itself to a certain entity only, namely the shareholders. At the very least, they also mean that SEA is an extension of disclosure into non-traditional areas such as providing information about employees, products, community service and the prevention or reduction of pollution (Mathews, 1997). Owen and Lehman (2000) stress that the domain of SEA is not restricted to the work of accountants as it involves symbiotic relationships with the community and this, they claim, points to an emancipated form of accounting that appraises the 'bottom line' to explore the extent to which corporations are acting in the public interest.

\subsection{Social Accounting}

Gray et al. (1996) broadly define social accounting as a study of all potential accounting, of which financial accounting is a limited subset. The term 'social accounting' has been used for several years in a number of different circumstances, hence it shows that there is a lack of precision which makes discussion of the area rather difficult (Mathews, 1991). However, two of the main uses of the term have been to describe non-traditional disclosures that are made on a voluntary basis by corporations. The purpose is to promote the identification, measurement and valuation of social impacts of the kind referred to as externalities. However, the type of accounting disclosures that is found in most of the literature, which best demonstrates practical social accounting, is the voluntary disclosure made by a corporation in the annual report via a supplementary booklet.

The four characteristics described in the previous section (refer to figure 1); namely, the financial description, specified economic events, defined accounting entities and provision of information for specified users are very much discussed in the concept of social accounting. The literature, for instance, tends to presume that the preparation of financial reports is made to present information on some particular activities which impact, among other things, the natural environment, employees and ethical issues. It can be inferred from this that social accounting provides a number of basic elements of an accounting model. The model consists firstly of a formal account which is prepared and communicated by an organisation. Secondly, it contains information on social and environmental aspects of the organisation's activities. Thirdly, the information is communicated to the internal and external 'participants' of the organisation (Gray et al., 1996).

\subsection{Environmental Accounting}

In the academic accounting literature of the 1970s, "environmental accounting" was expressed within the less unacceptable area known as "social accounting." This was to avoid the confrontation and misunderstanding that naturally ensue from any attempts at introducing environmental issues into the social sciences (Estes, 1976; Gray et al., 1996; Mathews, 1997). Possibly because there were few explicit economic or legal consequences associated with social accounting, broad academic interest in this area soon faded (Sefcik, Soderstrom and Stinson, 1997) and, in fact, "there was a considerable hostility to the concept during the 
1980s and beyond" (Gray, 2001). The recent upsurge in awareness of environmental issues, however, has led to renewed interest in new approaches to accounting that takes into consideration the organisation's interactions with society and the environment. Another factor is the substantial increase in international, federal, state and even local environmental regulation, as well as a rise in the number of lawsuits arising from violation of environmental laws and regulations (Sefcik et al., 1997). In addition, environmental issues, principally in terms of legislation and market forces, have implications for business in those areas that directly concern the accountants (Gray and Bebbington, 2001). Therefore the early conception of environmental accounting as part of social accounting emerged in the discussion on, among other things, green reporting (Owen, 1992) and accounting for the environment. In this regard, it is considered crucial to differentiate environmental accounting from the classical concept of natural resource accounting and its macroeconomic perspective. Still, a clear definition of 'environmental accounting' is somewhat vague (Sefcik et al., 1997).

Environmental accounting, according to Crowther (2000, p. 27), can be defined as "one subset of social accounting which is concerned with reporting the actions of the firm in so far as they relate to the environment in a physical rather than social sense". Accounting for environmental obligations require accounting for common use property, or shared resources, as well as accounting for stakeholder stewardship. They involve the rights and obligations of shareholders, customers, local communities affected by environmental degradation, and the electorate, as well as recognition of the 'being' rights of other species. While open to interpretation, Gray and Bebbington (2001) consider environmental accounting as covering all areas of accounting that may be affected by the business response to environmental issues, including new areas of 'eco-accounting'.

Economists Siebert and Antal (1979) look at the issues of intergenerational effects and sustainable development. They address some of the problems facing the industrialised world in the twentieth century which have their origins in the economics of the nineteenth century and which have been worsened by many factors, including the way in which accounting concentrates on monetary values, private ownership and the determination of value through the market place. Gray (1990a) considers the solutions put forth by the economists as implausible because of the latter's obsession with continued economic growth and reliance upon market-determined values. Furthermore, economists ignore ethical perspectives when discussing environmental matters and disdain regulation and the enforcement of standards of conduct.

In contrast, Gray favours a systems approach which demonstrates the interrelationship of society and the environment. Lehman (1999) demonstrates that environmental accounting as currently constituted is focused on the corporation as the accounting entity and mistakenly claims to be able to influence it. Despite the arguments and claims that the key problem of environmental accounting is the dearth of formalised definitions of what environmental assets or environmental contingencies are, Gray and Bebbington (2001) outline the coverage of environmental accounting as shown in Figure 2. 


\section{Environmental Accounting}

- Accounting for contingent liabilities/risks

- Accounting for asset re-valuations and capital projections

- Cost analysis in key areas such as energy, waste and environmental protection

- Investment appraisal to include environmental factors

- Development of new accounting and information systems to cover all areas of environmental performance

- Assessing the costs and benefits of environmental improvement programmes

- Developing accounting techniques which express assets and liabilities and costs in ecological (non-financial) terms

\section{Figure 2 - Coverage of environmental accounting}

Adapted from Gray and Bebbington (2001)

\subsection{Sustainability Accounting}

In 1987, the United Nations Commission on Environment and Development (the Bruntland Commission) drew attention to the fact that economic development often leads to deterioration, not improvement, in the quality of people's lives. The Commission, therefore, called for "a form of sustainable development which meets the needs of the present without compromising the ability of future generations to meet their own needs" (UNWCED, 1987, p.8). There are two fundamental issues. Firstly, development is not just about bigger profits and higher standards of living for a minority. It should be about making life better for everyone. Secondly, development should not involve the destruction or the irresponsible exploitation of the natural resources, nor should it engage in environmental pollution.

The neo-liberal view represented by the proponents of environmental accounting consider air, water, soil and other environmental elements as 'natural capital' which has to be preserved intact or renewed. They maintain that if this is not done, such capital will diminish. By assigning values to this capital, and using classical economic criteria, the incomes from particular courses of development can be measured against the corresponding depletion of capital. Consequently, projects embarked with a conscious consideration of potential environmental costs and benefits will ensure that long run sustainable development is achieved. In the area of waste discharge, for example, this principle has now been applied. The ongoing discussions and proposals on atmospheric pollution regulation have also seen the incorporation of the same principle. Despite these advances and the considerable interest that has been generated among economists over the possibility of incorporating environmental values in accounting procedures, the same proponents of environmental accounting are quick to acknowledge the significant difficulty in providing a valuation of 'natural capital.' This valuation problem becomes all the more complicated since it would need to take into account the value of resources to future generations whose livelihood and consumption patterns are unknown.

The definition of sustainability as provided by UNCWED (1987) encompasses both meeting the needs of the world's poor population and maintaining environmental resources for the future. The possible meanings and contradictions inherent in the term sustainability extend to the concept of sustainable development. Thus, according to Bebbington (1997, 2001), the definition of what constitutes a "sustainable society" becomes under-specified. According to Bebbington, the key structural question ingrained in sustainable development appears to be how to manage the economic systems such that development (under a revised definition) takes place without damaging the environment, on which all present and any 
future development rests. In reference to Hines (1988), Hopwood and Miller (1994) and Tinker (1991), Bebbington asserts that accounting plays a vital supporting role in the creation and perpetuation of the current economic order. Given this, any attempt to account for sustainability will need to reflect the tensions which exist between conventional accounting with its record of wealth accumulation and its focus on the pursuit of profit, and the demands for a just and equitable society.

\subsection{Socially Responsible Accounting}

The understanding and realisation that the corporations should be responsible not only to the shareholders but to a wider spectrum of society can be seen in Mathews' (1993) work on socially responsible accounting (SRA). SRA refers to disclosures of financial and nonfinancial, quantitative and qualitative information on the activities of an enterprise, which are of significance to society. This area of accounting also includes employee reports, human resource accounting (HRA), and accounting and industrial democracy. Alternative terms in common parlance are social responsibility disclosures and corporate social reporting (Mathews, 1991). At other times it is called corporate social responsibility (CSR) disclosures (Gray et al., 1987) and makes up a large proportion of the non-traditional voluntary information which organisations provide in annual reports. Typically, such disclosure is in the form of descriptive and un-audited statements pertaining to employees, products, community service, energy usage, and the environment.

The main idea underlying SRA is the broadening of the scope of accounting to include information on, among other things, the socio-economic situation, social and environmental issues and social responsibility. This notion implies that the accounting discipline should be extended beyond the traditional reporting of economic effects. Mathews, (1993) argues that a more socially responsible form of accounting is necessary and should be implemented. Its purpose is not to completely change society but to change and improve the present system by including measurement and reporting relationships that are currently excluded. In this perspective, it involves a wide variety of information, most of which is nonfinancial in nature. Generally, the information is of potential interest to employees and the public as well as to shareholders and creditors.

\subsection{Corporate Social Responsibility}

From the perspective of business organisations, according to Moir (2001), the notion of social responsibility covers a broad array of issues such as plant closures, employee relations, human rights, corporate ethics, community relations and the environment. This is a far cry from the neo-classical point of view which confines social responsibility of the business to the mere provision of employment and the payment of taxes.

The idea of strategic responsibility is clearly rooted in the notion of CSR and is linked to the concept of 'corporate governance' (Sarre, Doig and Fiedler, 2001). According to Weick (1999), the concept of CSR requires nurturing of an organisational 'culture of mindfulness', a cautious and constant awareness of the possibility of wrong-doing, a personal ethic of care, and an assumption of individual responsibility for the consequences of one's actions. This includes an organisational commitment to the constant evaluation of corporate health, safety and environmental practices to ensure that they not only conform to the law, but also at the same time perform to a standard that is safe, responsible and environmentally caring.

It is also important to make a distinction between CSR and corporate responsibility in that the latter implies the need to strive to meet universal generalisations, such as not to do any harm and to act ethically. Responsible business comes with better reputation and stakeholder engagements and in this regard the emphasis of business towards its stakeholders, 
the environment and society is now a reality rather than a concept (Raslan, 2007) For a company to prosper over the long term, it must continuously meet society's needs for goods and services without destroying natural or social capital. This mechanism is known as the 'triple bottom line' (Elkington, 1997), that is, acknowledging to the stakeholders via reporting the firm's wider financial, environmental and social responsibilities. It can also imply focusing on company profit performance that is balanced by demonstrated performance on delivering value to society, while improving the ecological environment (Walker, 2000). According to the European Commission (EC) (2001):

"CSR is a concept whereby companies integrate social and environmental concerns in their business operations and in their interactions with their stakeholders on a voluntary basis."

In this regard, three types of approaches are worth noting: shareholder, stakeholder and societal. The shareholder approach, regarded as the classical view on CSR (Quazi and O'Brien, 2000), views the maximisation of profits (Friedman and Friedman, 1982) as the primary responsibility of the business to the society, with particular focus on the shareholders. To that extent, this view relegates socially responsible activities to the task of governments and considers any responsibility of business enterprises to the society as only incidental to the aim of businesses, which is the creation of long-term value for the owners of the businesses.

The stakeholder approach points out that although organisations are accountable to its shareholders, they should also look into the interests of various other stakeholders that can affect or are affected by the achievement of an organisation's objectives (Freeman, 1984). In contrast to the above two approaches, the egalitarian societal approach considers companies as being wholly responsible to the society since they are regarded as a vital part of it. Table 1 outlines the definitions of the various terms and forms of SEA derived from this review.

From Table 1, it appears that SEA, social accounting, corporate social reporting and social responsibility accounting are generally accorded the same definitions. Environmental accounting and sustainability accounting are clearly a part of the whole area of SEA with different descriptions given to each of them. The term corporate social responsibility is discussed in the literature mostly from the business and management perspectives. Figure 3 below demonstrates the positioning of the accounting terms normally discussed as SEA and its branches, and the emergence of business management concepts in relation to the terms. 
Table 1 - Defining the new forms of accounting

\begin{tabular}{|c|c|}
\hline New Forms of Accounting & Definitions \\
\hline $\begin{array}{l}\text { Social and } \\
\text { environmental } \\
\text { accounting }\end{array}$ & $\begin{array}{l}\text { The process of communicating the social and environmental } \\
\text { effects of organisations' economic actions to particular interest } \\
\text { groups within society and to society at large. As such, it involves } \\
\text { extending the accountability of organisations (particularly } \\
\text { companies), beyond the traditional role of providing a financial } \\
\text { account to the owners of capital, in particular, shareholders. Such } \\
\text { an extension is predicated upon the assumption that companies do } \\
\text { have wider responsibilities than simply to make money for their } \\
\text { shareholders (Gray et al., 1996). }\end{array}$ \\
\hline Social accounting & $\begin{array}{l}\text { 1. Concerned with the measurement and communication of the } \\
\text { social and environmental effects of an organisation's economic } \\
\text { actions to particular interest groups within society and to } \\
\text { society at large, beyond the traditional role of providing a } \\
\text { financial account to the owners of capital, in particular } \\
\text { shareholders. (Gray et al., 1987). } \\
\text { 2. The measurement and reporting, internal or external, of } \\
\text { information concerning the impact of an entity and its activities } \\
\text { on society (Estes, 1976). }\end{array}$ \\
\hline $\begin{array}{l}\text { Corporate social } \\
\text { reporting/corporate social } \\
\text { disclosure }\end{array}$ & $\begin{array}{l}\text { Involves reporting by companies and other organisations on wider } \\
\text { social and economic aspects of the organisation's performance } \\
\text { than profit and financial position alone (Perks, 1993). }\end{array}$ \\
\hline Environmental accounting & $\begin{array}{l}\text { 1.The approach to measuring organisational activity through } \\
\text { accounting for the actions of a firm in relation to the external } \\
\text { environment, and the impact of those activities of the firm upon } \\
\text { external stakeholders (Crowther, 2000). } \\
\text { 2. The collection, recording, classification, extraction and } \\
\text { summary of information relating to the nature and } \\
\text { environment. }\end{array}$ \\
\hline Sustainability accounting & $\begin{array}{l}\text { Capable of being continued with minimal long-term effect on the } \\
\text { environment. }\end{array}$ \\
\hline
\end{tabular}

Note: The phrases in italics indicate similar descriptions of the definitions 


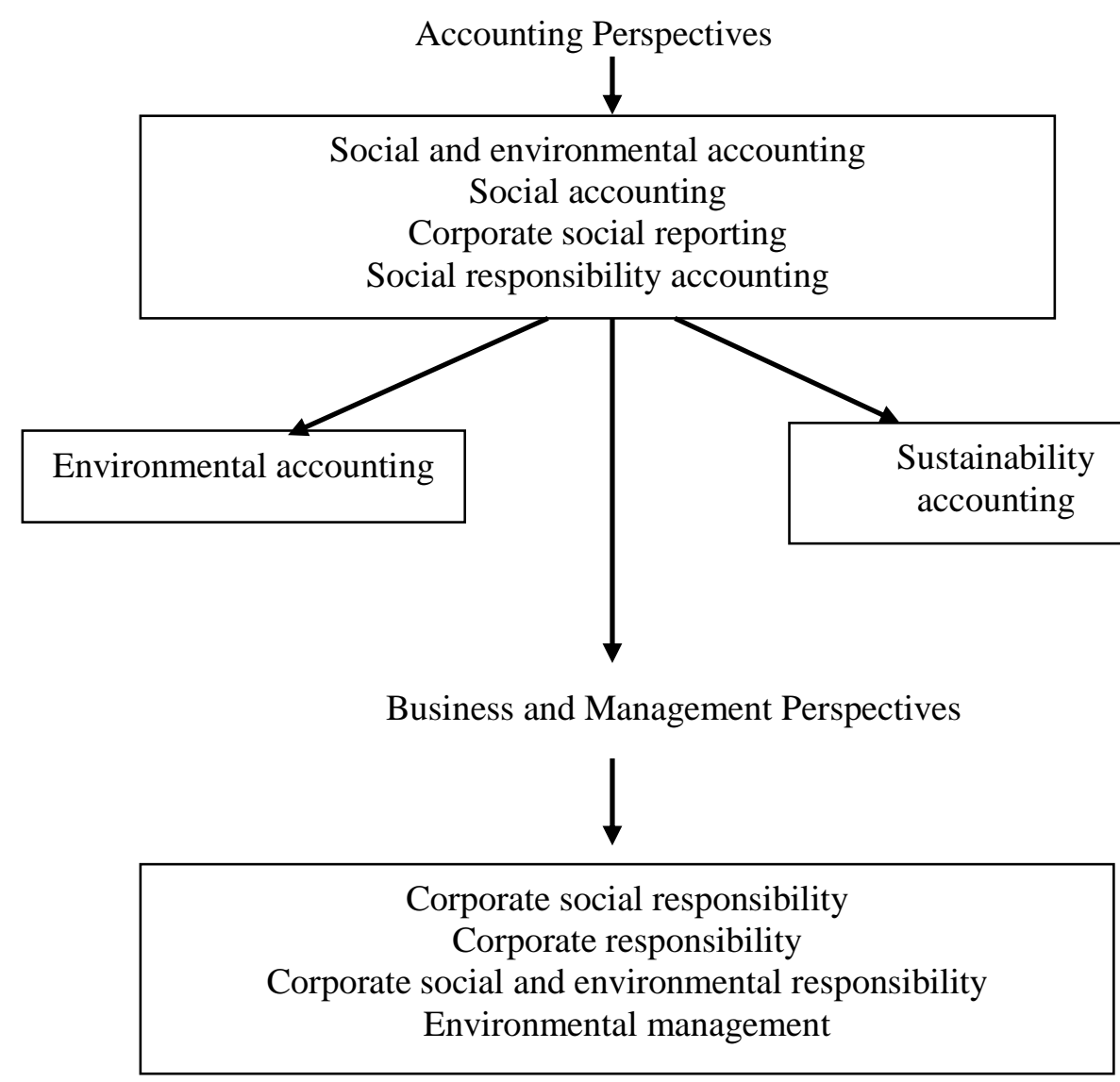

Figure 3 - Positioning the new forms of accounting and business management

\section{Concepts and Theories Underlying SEA}

Recognising the inadequacy of conventional accounting with its undue emphasis on profits and financial reporting, and coupled with the fact that accounting is after all a social construct that should be malleable to changes in the society, the evolution of an alternative form of accounting is clearly in order. It is justified by the concepts of organisational legitimacy and the social contract of business (and government) with society (Mathews, 1993; 2004). In this respect, accounting as the language of business needs some new information to cater for the interest of parties other than the shareholders. This section presents the main concepts and theories used to explain the relevance of SEA. Other than the legitimacy theory a review is made at the concept of accounting and accountability and the general system theory (GST).

\subsection{Accounting and Accountability}

Perks (1993) defines accountability as the obligation to give an account, and illustrates the accountability relationship in terms of the agency theory. In a company, the shareholders are treated as being the Principals and the company directors are their Agents. On the basis of a contractual relationship, the Agents are entrusted with the control over the resources of the Principals but on the condition that they safeguard and manage the resources in the most efficient and effective way. The accounting model that encapsulates this relationship of accountability is based on the idea that, in companies, the ownership function is separated from the stewardship, hence the need for the directors to be accountable to shareholders. In order to ensure the continuance of such accountability, Lovell (1997) points out that Principals allow the Agents to participate in part of the Principals' gains. In addition, Principals can also implement effective control systems to keep tab of Agents' actions and to provide immediate feedback of any adverse performances. According to Lovell, the 
underpinning rationale for the control mechanism is the assumption that individuals are, by nature, self-seeking, untrustworthy and inherently lazy.

Gray et al. (1996) argue that the 'account' the accountants have to offer emphasises purely financial information and is intended mainly for investors and creditors. Thus, the typical corporate information system is designed solely to collect, process and report financial results, not other social and environmental performance information. Due to the conventional orientation of accounting knowledge and discipline, it is difficult for the accounting practitioners to accept the growing demands of society.

In summary, the current accounting tradition that is steeped in the sphere of the private sector, limits the boundary of the accountants' responsibilities toward the interests of many in the society as well as the natural environment. The accounting profession is a social construct and this implies that it is implicated in the relationship between the world's economic, social, political and environmental systems. Moreover, environmental issues are business issues and thus they involve accounting. Due to these reasons, Gray et al. (1996) argue that SEA and disclosures are necessary to the development of accountability.

\subsection{General Systems Theory and System View of Accountants}

GST views the world as a hierarchical series of systems - supra-system, system and subsystem - that are interrelated across their boundaries (Mathews, 1993; Gray et al., 1996; Gray and Bebbington, 2001). According to Mathews (1993), societal accounting theorists reckon that economic activity (and a great deal of social activity as well) forms a vast suprasystem. Within this supra-system, individual systems (or industries) operate. Individual enterprises form subsystems (and within them even smaller divisions exist). These diverse units are linked together by inputs and outputs of resources which include various kinds of information. The interaction of the system with the environment (or supra-system) is only partly demonstrated by the existing system of financial accounting. Currently, accounting information directed to the supra-system is limited to the use of shareholders, debt-holders and the government. In line with greater social and environmental awareness, this list of stakeholders is gradually growing to include customers, employees, trade unions and the general public. The range of information types suggests that the current conventional accounting must undergo some fundamental changes for it to meet this growing need for information.

Another way of looking at the systems theory is to see the interrelatedness of accounting with other systems, be they 'social', 'political', or 'ethical'. These interactions happen within and between organisational systems and between those organisational systems and individuals, groups, communities, societies, nations and even the non-human elements of the planetary natural environment (see Mathews, 1993; Gray et al., 1996; Gray and Bebbington, 2001). The protagonists of this view maintain that GST is not a theory but a helpful way of thinking - a mental framework with which one can stand back from issues and see them in a broader context. The theory asserts that accounting, which is often considered as a constrained system, should be perceived in a broader context. Societies, organisations, economics, accounting, ecology are all systems and they interact. The intellectual foundations of conventional accounting, however, are limiting the explicit interaction of accounting with these other systems.

Traditionally, the life of an accountant centres on the organisation that is located in a 'substantive environment' (see Figure 4), bounded with reference to only those events which the accountant traditionally recognises - those economic events which can be described in

\footnotetext{
${ }^{1}$ The word 'environment' does not necessarily have ecological connotations in this context (Gray and Bebbington, 2001, p. 22)
} 
financial terms. The accountant's book-keeping and financial reporting activities make it explicit the limited view the profession takes of the world. However, an organisation is made up of a complex web of interactions drawing from and contributing to the social world in various positive and negative ways. These interactions can both be implicit or explicit and subject to interpretations and perceptions. The accountants, therefore, must be able to reflect explicitly the reality of these relationships in order to account fully the activities of the organisation (Gray, 1990b).

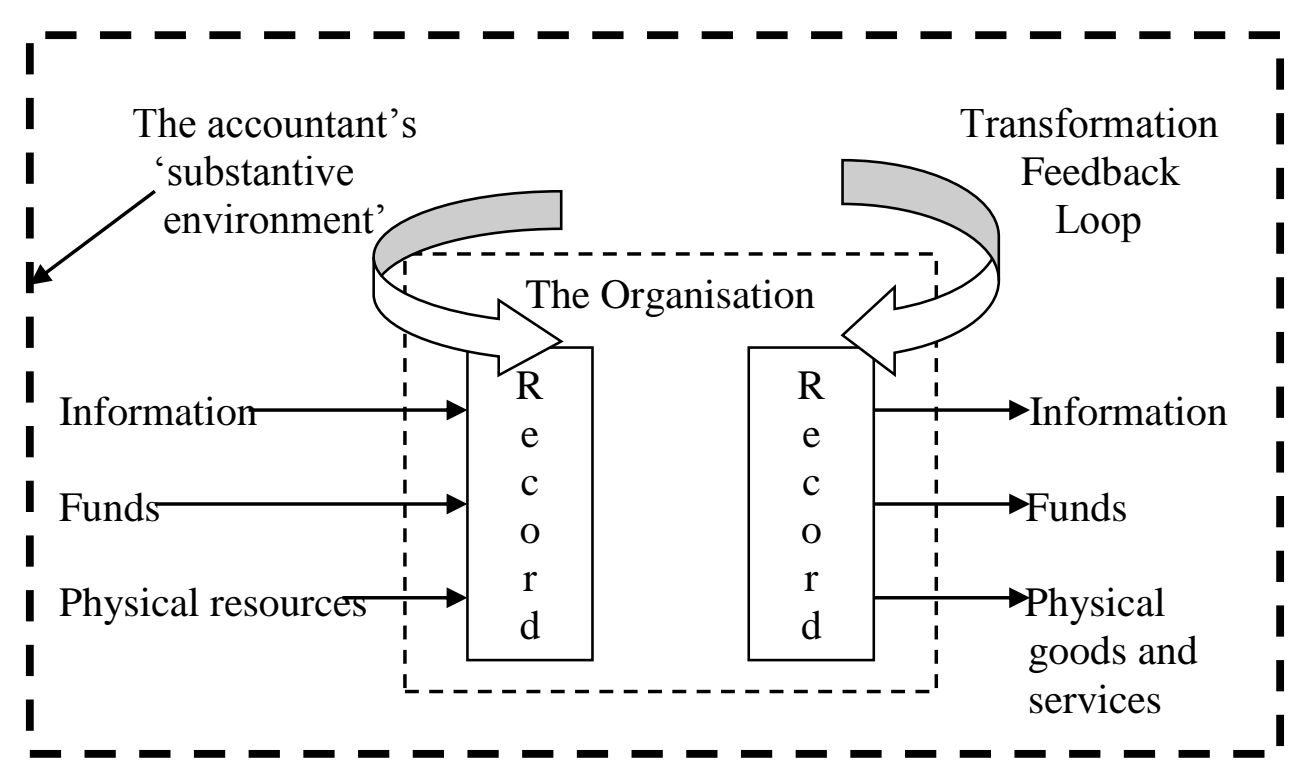

Figure 4 - A systems view of accounting, organisations and the environment Adapted from Gray and Bebbington (2001)

\subsection{Organisational Legitimacy}

Mathews (1993) considers both the moral and pragmatic reasons underlying the adoption of social and environmental disclosures by organisations in his discussion of organisational legitimacy. He explains that if on the one hand, a manager wishes to present the corporation as acting within a social contract framework, he is in fact trying to legitimise the organisation in the eyes of the society where the organisation resides. This kind of legitimacy panders to the moral issue. On the other hand, a manager may not believe that constituencies are entitled to the disclosures, but nevertheless chooses to make disclosures to satisfy a demand for information and thereby legitimise the organisation with the public. This second form of legitimacy, in turn, panders to the sentiments of the public. In both forms, however, the common denominator is the need for visibility, social approval and political support albeit the fact that different organisations differ considerably in their degrees of need for this kind of legitimacy. Mathews asserts that the implications which the notion of organisational legitimacy has for the management of the corporation include better communication with the society. Figure 5 illustrates some of the components of concepts and theories which justify the existence of non-conventional accounting in its various forms. 


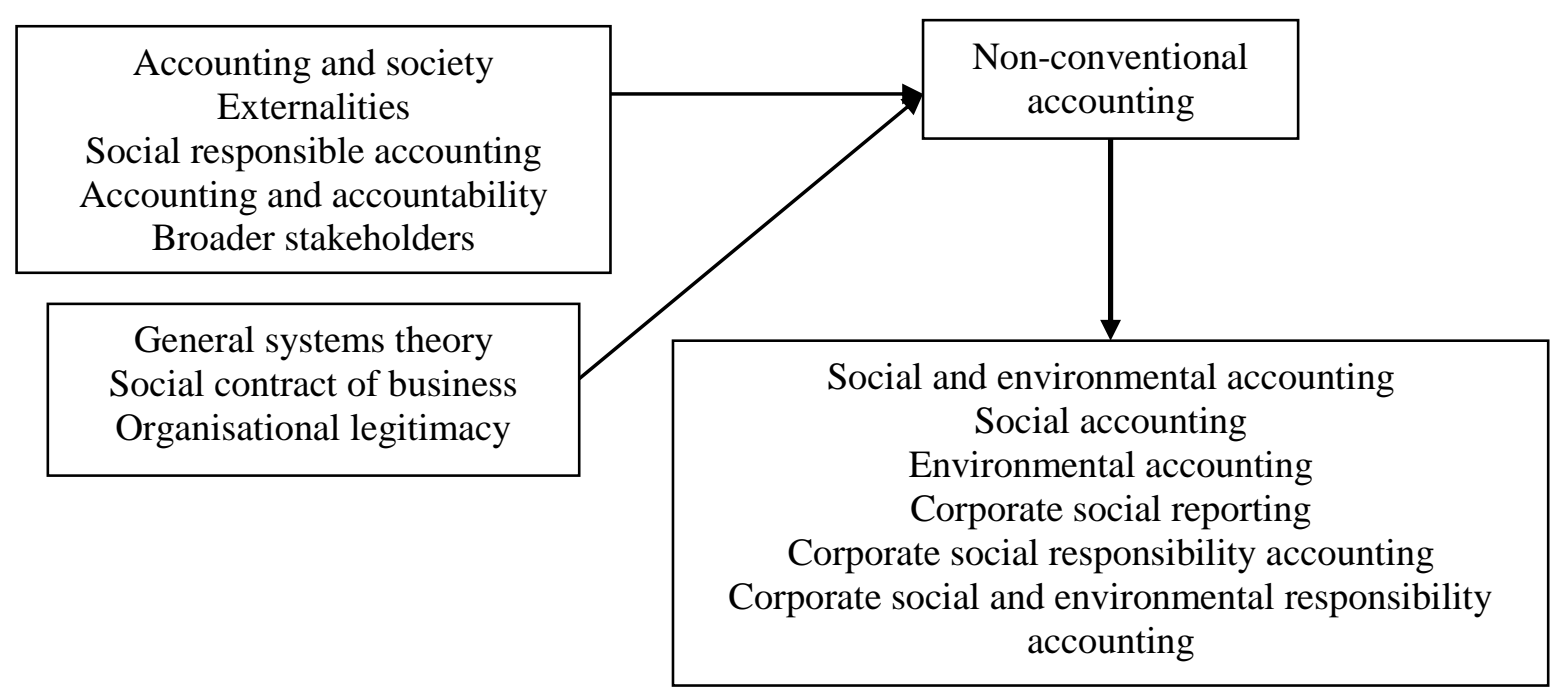

Figure 5 - Concepts, theories and the new forms of accounting

\section{Conclusion}

In summary, SEA seeks to confront traditional accounting by undermining the foundation of pristine liberal economy, namely the maximisation of profits and shareholders' wealth. By infusing accounting with a broader dimension, SEA breaks the shackles and limitations of conventional accounting, thus paving the way for accountants to act as agents of change. Although SEA does not adhere to pronounced values or social norms, such as Islam or any other religion, it seeks to recognise the ill effects on society and the environment through accounting. These elements of humanity which SEA embraces is a value in itself and should be guarded and improved.

\section{References}

Abu-Sway, M. (1998) "Towards an Islamic jurisprudence of the environment", at http://homepages.iol.ie/\%7Eafifi/Articles/environment.htm (date accessed: 21 March 2006).

Adams, C. A., and Gonzalez, C. L. (2007), "Engaging with organisations in pursuit of improved sustainability accounting and performance", Accounting, Auditing \& Accountability Journal, 20(3): 333-355.

American Accounting Association (AAA) (1977) Statement on Accounting and Theory Acceptance. Sarasota: AAA.

Beams, F.A. and Fertig, P.E. (1971) "Pollution control through social costs conversion", Journal of Accountancy, 141: 37-42.

Bebbington, J. (1995) "Teaching social and environmental accounting: A review essay", Accounting Forum, 19 (2/3): 263-273.

. (1997) "Engagement, education and sustainability: A review essay on environmental accounting", Accounting, Auditing and Accountability Journal, 10(3): 365-381.

- (2001) "Sustainable development: A review of the international development, business and accounting literature", Accounting Forum, 25(2): 128-158.

Bloom, R. and Heymann, H. (1986) "The concept of 'social accountability' in accounting literature", Journal of Accounting Literature, 5:167-182.

Churchman, C.W. (1971) "On the facility, felicity, and morality of measuring social change", Accounting Review, 46(1): 30-35. 
Cooper, D.J. and Sherer, M.J. (1984) "The value of corporate accounting reports: arguments for a political economy of accounting", Accounting, Organizations and Society, 9 (3/4): 207-232.

Crowther, D. (2000) Social and Environmental Accounting, London: Pearson Education Limited.

Dey, C. (2007), "Social accounting at Traidcraft plc: A struggle for the meaning of fair trade", Accounting, Auditing \& Accountability Journal, 20(3): 423-445.

Elkington, J. (1997) Cannibals With Forks: the Triple Bottom Line of $21^{\text {st }}$ Century Business, Oxford: Capstone Publishing.

Estes, R. W. (1976) Corporate Social Accounting, New York: John Wiley and Sons.

European Commission (2001), Promoting a European Framework for Corporate Social Responsibility, at http://ec.europa.eu/ (date accessed: 3 February 2005).

Freeman, R. E. (1984) Strategic Management: A Stakeholder Approach, Marshfield: Pitman Publishing Inc.

Friedman, M. and Friedman, R, D. (1982) Capitalism and Freedom, Chicago, Illinois: University of Chicago Press.

Gambling, T. (1974) Societal Accounting, London: George Allen \& Unwin. . (1978) Beyond the Conventions of Accounting, London: McMillan Press.

Gray, R. H. (1990a) "Accounting and economics: The psychopathic siblings, a review essay", British Accounting Review, 22(4): 373-88.

. (1990b) The greening of accountancy: the profession after Pearce, Certified Research Report 17, Chartered Associations of Certified Accountants, London.

and Bebbington, J. (2001) Accounting for the Environment, London: Sage Publications.

, Owen, D. and Maunders, K. (1987) Corporate Social Reporting: Accounting and Accountability, London: Prentice-Hall.

, Owen, D. and Adams, C. (1996) Accounting And Accountability - Changes and Challenges in Corporate Social and Environmental Reporting, Harlow, Essex: Prentice Hall.

Henderson, S. and Peirson, G. (1988) "The conceptual framework and the objectives of financial reporting", in Issues in Financial Accounting, Fourth edition, Melbourne: Longman Cheshire: 2-39.

Hines, R.D. (1988) "Financial accounting: in communicating reality, we construct reality", Accounting, Organizations and Society, 13(3): 251-61.

Hopwood, A. G. and Miller, P. (eds) (1994) Accounting as Social and Institutional Practice, Cambridge: Cambridge University Press.

Humphrey, C., Lewis, L. and Owen, D. (1996) "Still too distant voices? Conversations and reflections on the social relevance of accounting education", Critical Perspectives in Accounting, 7(1): 77-99.

Lehman, G. (1999) "Disclosing new worlds: a role for social and environmental accounting and auditing", Accounting, Organizations and Society, 24(3): 217-41. . (2001) "Accounting Millennium themes: Toward accounting in a steady-state", Accounting Forum, 25(3): 211-214.

. (2004) "Accounting, accountability, and religion: Charles Taylor's Catholic modernity and the malaise of a disenchanted world", Accounting and the Public Interest, 4: 43-61.

Linowes, D.F. (1972) "Socio-economic accounting”, Journal of Accountancy, 133: 37-42.

Lovell, A. (1997) "Some thoughts on Kohlberg's hierarchy of moral reasoning and its relevance for accounting theories of control", Accounting Education: an International Journal, 6(2): 147-162. 
Mathews, M. R. (1991) Social accounting and the development of accounting education, South East Asia University Accounting Teachers Conference, January 21-23, pp.478494.

. (1993) Socially Responsible Accounting, Chapman \& Hall, London.

. (1995) "Social and environmental accounting: A practical demonstration of ethical concern?", Journal of Business Ethics, 14(8): 663-674.

. (1997) "Twenty-five years of social and environmental accounting research: Is there a silver jubilee to celebrate?", Accounting, Auditing \& Accountability Journal, 10(4): 481-531.

. (2004) "Developing a matrix approach to categorise the social and environmental accounting research literature", Quality Research in Accounting and Management, 1(1): 30-45.

and Perera, M. H. B. (1996) Accounting Theory and Development, Third edition, Australia: Thomas Nelson.

Mobley, S.C. (1970) "The challenges of socio-economic accounting", Accounting Review, 45(4): $762-768$.

Moir, L. (2001) "What do we mean by corporate social responsibility?", Corporate Governance, 1(2): 16-22.

Owen, D. (ed), (1992) Green Reporting: Accountancy and the Challenge of the Nineties, London: Chapman \& Hall.

. (2004) Adventures in social and environmental accounting and auditing research: A personal reflection, in Humphrey, C. and Lee, B. (eds.) The Real Life Guide to Accounting Research, Oxford: Elsevier Science.

Owen, D. L., Humphrey, C. and Lewis, L. (1994) Social and Environmental Accounting Education in British Universities, Certified Research Report 39, London: The Chartered Association of Certified Accountants.

Owen, D. and Lehman, G. (2000) "Social and environmental accounting: Trends and directions for the future", Accounting Forum, 24(1): 1-4.

Perks, R. W. (1993) Accounting and Society, London: Chapman \& Hall.

Quazi, A. M. and O' Brien, D. (2000) "An empirical test of a cross-national model of corporate social responsibility", Journal of Business Ethics, 25(1): 33-51.

Raslan, J. (2007) "Responsible business - raising the bar", Corporate Responsibility, November: 4.

Sarre, R., Doig, M. and Fiedler, B. (2001) "Reducing the risk of corporate irresponsibility: The trend to corporate social responsibility", Accounting Forum, 25(3): 300-318.

Sefcik, S. E., Soderstrom, N. S. and Stinson, C. H. (1997) "Accounting through greencolored glasses", Issues in Accounting Education, 12(1): 129-140.

Seidler, L. J. (1975) Social Accounting: Theory, Issues, and Cases, California: Melville Publishing Company.

Siebert, H. and Antal, A. B. (1979) The Political Economy of Environmental Protection, New York: JAI Press.

Stevenson, L. (2002) "Social and environmental accounting teaching in UK and Irish universities: A research note on changes between 1993 and 1998", Accounting Education: an International Journal, 11(4): 331-346.

Tinker, T. (1991) "The accountant as partisan", Accounting, Organizations and Society, 16(3): 297-310.

United Nations World Commission on Environment and Development (UNWCED) (1987) Our Common Future, Oxford: Oxford University Press.

Walker, D. H.T. (2000) "Client/customer or stakeholder focus? ISO 14000 EMS as a construction industry case study", The TQM Magazine, 12(1): 18-26. 
Weick, K. (1999) Why efficiency is the enemy of safety, The Manager, www.themanager.com.au, June (Date accessed, 3 April, 2003). 